\title{
Efficacy of Fungicides on Sclerotinia sclerotiorum and Their Potential for Control of Sclerotinia Stem Rot on Soybean
}

\author{
D. S. Mueller, Department of Crop Sciences, University of Illinois, Urbana 61801; A. E. Dorrance, Department of \\ Plant Pathology, R. C. Derksen, USDA/ARS, and E. Ozkan, Department of Food Agriculture and Biological En- \\ gineering, Ohio State University, Wooster 44691; J. E. Kurle, Department of Plant Pathology, University of Minne- \\ sota, St. Paul 55108; C. R. Grau, Department of Plant Pathology, and J. M. Gaska, Department of Agronomy, \\ University of Wisconsin, Madison 53706; G. L. Hartman, USDA/ARS, and C. A. Bradley and W. L. Pedersen, \\ Department of Crop Sciences, University of Illinois, Urbana 61801
}

\begin{abstract}
Mueller, D. S., Dorrance, A. E., Derksen, R. C., Ozkan, E., Kurle, J. E., Grau, C. R., Gaska, J. M., Hartman, G. L., Bradley, C. A., and Pedersen, W. L. 2002. Efficacy of fungicides on Sclerotinia sclerotiorum and their potential for control of Sclerotinia stem rot on soybean. Plant Dis. 86:26-31.

Sclerotinia stem rot of soybean, caused by Sclerotinia sclerotiorum, is a major disease in the north central region of the United States. One approach to managing Sclerotinia stem rot on soybean is the use of fungicides. S. sclerotiorum was assayed for sensitivity to benomyl, tebuconazole, thiophanate methyl, and vinclozolin in pure cultures on agar medium, inoculated soybean seedlings, detached inoculated leaves, and in experimental field plots. To evaluate the inhibitory effect of four fungicides on growth of $S$. sclerotiorum in vitro, potato dextrose agar (PDA) was amended with the fungicides at six concentrations. Based on measurements of fungal radial growth, vinclozolin was the most effective in inhibiting $S$. sclerotiorum mycelial growth at $1.0 \mu \mathrm{g}$ a.i. $/ \mathrm{ml}$ of PDA. Ranges of reduction of radial growth of 91 isolates of $S$. sclerotiorum on PDA amended with thiophanate methyl and vinclozolin were 18 to $93 \%$ and 93 to $99 \%$, respectively, when compared with the nonamended agar control. Benomyl, thiophanate methyl, and vinclozolin applied to greenhouse-grown seedlings prevented $S$. sclerotiorum from expressing symptoms or signs on leaf tissue. Detached leaves sprayed with thiophanate methyl and then inoculated with mycelial plugs of $S$. sclerotiorum did not express symptoms or signs. Of 13 different environments in Illinois, Indiana, Ohio, and Wisconsin from 1995 through 2000, six had low Sclerotinia stem rot incidence $(<1 \%)$, three environments had low to moderate Sclerotinia stem rot incidence ( 5 to $25 \%$ ), and four environments had high Sclerotinia stem rot incidence $(>25 \%)$. When disease incidence was high, no consistent control of Sclerotinia stem rot was observed with benomyl or thiophanate methyl using different application systems. However, under low disease incidence, spray systems that were able to penetrate the canopy reduced the incidence of Sclerotinia stem rot an average of $50 \%$.
\end{abstract}

Sclerotinia stem rot of soybean (Glycine $\max$ (L.) Merr.), caused by Sclerotinia sclerotiorum (Lib.) de Bary, is a major disease in the north central region of the United States (9). There were severe outbreaks of this disease in 1992, 1994, and 1996 in this region $(9,10,12)$. In 1994 , Sclerotinia stem rot was ranked the most severe soybean disease in Argentina and the second most important disease in the United States (27).

Corresponding author: W. L. Pedersen

E-mail: wpederse@uiuc.edu

Trade and manufacturers' names are necessary to report factually on available data; however, the USDA neither guarantees nor warrants the standard of the product, and the use of the name by USDA implies no approval of the product to the exclusion of others that may also be suitable.

Accepted for publication 21 September 2001.

Publication no. D-2001-1029-01R

(C) 2002 The American Phytopathological Society
Crop management practices and cultivar selection contribute to the control of Sclerotinia stem rot, but the effectiveness of these tactics can be modified by inoculum potential. Furthermore, other pests and pathogens, government regulations, economics, and intended use of soybean crop may be obstacles to the use of agronomic practices and partially resistant cultivars to control Sclerotinia stem rot. Management plans for control of Sclerotinia stem rot would benefit from a tactic that could be implemented on a need basis during the growing season. Fungicides would offer this flexibility and also augment preventive measures.

Blossoms serve as an energy source to support ascospore infection of healthy plants $(1,3)$. Because flower petals are the sites of primary colonization, the application of fungicides must be directed at flower petals, especially in the lower portions of the crop canopy. Once established, infections can spread to leaves, petioles, internodes, and also to adjacent plants through contact with diseased plants.
The use of fungicides to control S. sclerotiorum has been evaluated on snap bean (Phaseolus vulgaris L.). However, control has been inconsistent $(14,24)$, primarily due to difficulties in achieving good coverage with fungicides and timing of application in relationship to ascospore release. The level of control is directly related to the number of blossoms within the canopy that are treated with fungicide (19). For example, the lower half of the dry bean canopy received little or no fungicide with an aerial application (26).

Many of the same problems that limit the use of foliar fungicides on snap bean may also exist in soybean. For example, indeterminate soybean cultivars flower over a 1- to 5-week period, which provides many opportunities for infection to occur, even with two fungicide applications. Moreover, the canopy of soybean is similar to the snap bean's canopy, where it is difficult for the fungicides to penetrate the canopy and cover the blossoms. This is especially true in soybean fields with row spacing less than $76 \mathrm{~cm}$.

The objectives of this study were to (i) investigate the effect of different concentrations of several fungicides on mycelial growth of S. sclerotiorum; (ii) determine the effect of two fungicides on the growth of various isolates of S. sclerotiorum; (iii) evaluate several fungicides for control of $S$. sclerotiorum on soybean in the greenhouse and field; and (iv) assess different spray application techniques for fungicidal control of $S$. sclerotiorum in soybean.

\section{MATERIALS AND METHODS}

In vitro growth of $S$. sclerotiorum on fungicide-amended agar. Potato dextrose agar (PDA; Difco, Detroit, MI) was autoclaved at $122^{\circ} \mathrm{C}$ for $15 \mathrm{~min}$ and cooled to 45 to $50^{\circ} \mathrm{C}$. Filter sterilized benomyl (Benlate $50 \mathrm{WP}$, DuPont, Wilmington, DE), tebuconazole (Folicur 3.6 F; Bayer Corporation, Kansas City, MO), thiophanate methyl (Topsin M 70WP; Elf Atochem, Philadelphia, PA), and vinclozolin (Ronilan 50 WP; BASF Corp., Research Triangle Park, NC) were diluted in distilled water and added to PDA to yield $0.1,1,10$, 50,100 , and $500 \mu \mathrm{g}$ a.i./ml of PDA of each fungicide. Benomyl was diluted in $95 \%$ EtOH before being added to the tempered 
agar, and nonamended PDA was used as a control. Twenty milliliters of amended or nonamended PDA was poured into 9-cmdiameter petri dishes. Initial cultures of $S$. sclerotiorum (SSR-113; Henry Co., Geneseo, IL) were grown on nonamended PDA. Plugs (6-mm-diameter) were taken from the actively growing margins of the colony, and one plug was transferred to the center of five replicated plates of each treatment. Plates then were placed in a growth chamber at $25^{\circ} \mathrm{C}$ under constant fluorescent light at $100-\mu \mathrm{E} \cdot \mathrm{m}^{-2} \cdot \mathrm{s}^{-1}$. The diameter of the radial growth was measured daily for 3 days after the transfer. Area under mycelia growth curve (AUMGC) was calculated using colony diameter as the dependent variable and the three dates as the independent variable (20). The experiment was arranged in a completely randomized design and was done three times.

Another in vitro assay was done to determine the effective concentration of vinclozolin and thiophanate methyl for a $50 \%$ reduction in growth $\left(\mathrm{EC}_{50}\right)$ of $S$. sclerotiorum isolate SSR-113. Vinclozolin was diluted to $0.1,0.3,0.7,1.0,3.0,5.0,7.0$, and $10 \mu \mathrm{g}$ a.i./ml of PDA, and thiophanate methyl was diluted to $0.1,0.3,0.7,1.0,3.0$, 7.0, 10, 20, 30, 40, and $50 \mu \mathrm{g}$ a.i./ml of PDA. Nonamended PDA was used as a control. The diameter of the radial growth was measured daily for 3 days after the transfer. AUMGC was calculated using colony diameter as the dependent variable and the three dates as the independent variable (20). The experiment was arranged in a completely randomized design, there were five replications (plates) per treatment, and the experiment was done twice.

Vinclozolin and thiophanate methyl both were diluted to $1.0 \mu \mathrm{g}$ a.i./ml of PDA to evaluate the sensitivity of 91 isolates of $S$. sclerotiorum. Isolates grown on nonamended PDA were included as a control. The same experimental procedure was used as previously described with five replications per treatment, and the experiment was repeated. These isolates are part of a soybean pathogen collection housed at the National Soybean Research Center at the University of Illinois. The isolates originated from four countries, eight states, 19 counties within Illinois, and nine different hosts. A complete list of isolates used can be obtained from the corresponding author.

Greenhouse experiment. Four fungicides were evaluated for their control of $S$. sclerotiorum on two soybean cultivars, NK S19-90 (Syngenta Seeds, Golden Valley, $\mathrm{MN}$ ) and BSR101, which are partially resistant and susceptible to Sclerotinia stem rot, respectively (16).

A highly aggressive isolate of $S$. sclerotiorum (SSR-113) from soybean was used for this study (17). Inoculum was prepared by mixing $500 \mathrm{ml}$ of wheat seed (Triticum aestivum L.), $500 \mathrm{ml}$ of deionized water, $10 \mu \mathrm{g}$ of sucrose, and $2 \mathrm{ml}$ of 1 $\mathrm{N} \mathrm{HCl}$ in a 3.8-liter plastic container. The mixture was autoclaved for $1 \mathrm{~h}$ at $121^{\circ} \mathrm{C}$ on two consecutive days. Three-day-old cultures growing on PDA were cut into 1 $\mathrm{cm}^{2}$ plugs. Approximately 10 plugs were transferred into each plastic jug and incubated at $23^{\circ} \mathrm{C}$ for 7 days, being shaken vigorously twice a day. The colonized wheat grain was air-dried for 2 days and ground through a 3-mm stainless steel screen using a Wiley mill (Arthur H. Thomas Co., Philadelphia, PA). The inoculum was stored at $4^{\circ} \mathrm{C}$.

A mist chamber, $4.3 \times 1.4 \times 0.9 \mathrm{~m}$, was constructed on a greenhouse bench. Sand was evenly spread over a plastic sheet covering the bench to a depth of $4 \mathrm{~cm}$. Another transparent plastic sheet was draped over the frame to enclose the chamber. Two humidifiers (Herrmidifer Co., Lancaster, PA) were placed at each end of the chamber to maintain the relative humidity at $100 \%$. A humidostat was placed in the center of the chamber, but not directly in the path of the humidified air. Temperature was maintained at $21 \pm 4^{\circ} \mathrm{C}$.

Approximately $800 \mathrm{ml}$ of a soil/sand mixture (1:1) was added to $947-\mathrm{ml}$ poly- propylene containers. Three 3-mmdiameter holes were drilled into the bottom of the containers for drainage. Six seeds of each cultivar were planted in each container, and the containers were arranged in a randomized complete block design with four replications. The fungicides benomyl, tebuconazole, thiophanate methyl, and vinclozolin were applied at recommended rates. The plants were uniformly sprayed at growth stage V2 (7) using a greenhouse sprayer calibrated to apply the equivalent of 238 liters/ha using XR8003VS flat spray tips (Spraying Systems Co., Wheaton, IL). After $24 \mathrm{~h}$, these plants were lightly misted with water, and approximately $0.1 \mathrm{~g}$ of ground inoculum was applied evenly over every leaf. Plants were then placed in a humidity chamber and after 3 days were individually rated on a scale of 0 to 5 , where $0=$ no disease, $1=$ lesion $<5 \mathrm{~mm}$ on leaf, $2=$ lesion $>5 \mathrm{~mm}$ on leaf, $3=$ lesion $>5 \mathrm{~mm}$ on leaf and start of stem colonization, $4=$ severe stem colonization, and $5=$ plant completely dead. The experiment was done three times.

Soybean plants, grown in the greenhouse similarly to the previous study, were sprayed with the same four fungicides at growth stage V2 (7) at the same rates and allowed to dry for 1 day. Trifoliolate leaflets from each treatment were detached and placed on filter paper saturated with water in a 9-cm-diameter petri plate. Agar plugs, 6-mm-diameter, were transferred from actively growing margins of isolate SSR113 of $S$. sclerotiorum to the center of each leaflet. The detached leaves were incubated in a growth chamber at $25^{\circ} \mathrm{C}$ under constant fluorescent light at $100-\mu \mathrm{E} \cdot \mathrm{m}^{-2} \cdot \mathrm{s}^{-1}$ light. Water was added as needed to keep the filter paper saturated for 4 days. The length and width of the lesion was determined daily for 4 days after inoculation, and area under disease progress curve (AUDPC) values were calculated using lesion length and width as the dependent variable and the four dates as the independent variable (25). The experiment was

Table 1. Field location, soybean cultivar(s), plant population, row width, and previous crop of fields used for evaluation of efficacy of fungicide for management of Sclerotinia stem rot under field conditions in three states from 1995 to 2000

\begin{tabular}{|c|c|c|c|c|c|}
\hline $\begin{array}{l}\text { Environment } \\
\text { and year }\end{array}$ & Location & Cultivar(s) ${ }^{\mathbf{a}}$ & $\begin{array}{l}\text { Seed population } \\
\quad(\text { seeds/ha })\end{array}$ & $\begin{array}{l}\text { Row width } \\
\quad(\mathrm{cm})\end{array}$ & Previous crop \\
\hline IL-98 & Watseka, IL & Pioneer 9363 & 556,000 & 19 & Soybean \\
\hline IL-99 & Woodstock, IL & Pioneer 9163 & 556,000 & 19 & Corn \\
\hline IN-00 & Kentland, IN & Dairyland DSR272RR & 445,000 & 76 & Corn \\
\hline OH-98 & Mt. Vernon, $\mathrm{OH}$ & Croton 3.9 & 445,000 & 19 & Soybean \\
\hline OH-99 & Wooster, OH & Croton 3.9 & 494,000 & 38 & Corn \\
\hline $\mathrm{OH}-00$ & Shreve, OH & Asgrow/Monsanto AG3003 & 445,000 & 19 & Corn \\
\hline WI-95 & Waunakee, WI & NK Brand S19-90 BSR101 Sturdy & 544,000 & 19 & Soybean \\
\hline WI-96 & Waunakee, WI & NK Brand S19-90 BSR101 Sturdy & 544,000 & 19 & Corn \\
\hline WI-97 & Waunakee, WI & NK Brand S19-90 & 544,000 & 19 & Soybean \\
\hline WI-98-1 & Waunakee, WI & $\begin{array}{l}\text { Kaltenberg KB256RR } \\
\text { Asgrow/Monsanto AG2501 }\end{array}$ & 593,000 & 19 & Corn \\
\hline WI-98-2 & Waunakee, WI & Kaltenberg KB256RR & 519,000 & 38 & Corn \\
\hline WI-99 & Arlington, WI & $\begin{array}{l}\text { Kaltenberg KB256RR } \\
\text { Asgrow/Monsanto AG2501 }\end{array}$ & 519,000 & 38 & Small grains \\
\hline
\end{tabular}

\footnotetext{
${ }^{a}$ Cultivars NK Brand S19-90, Asgrow/Monsanto AG 2501 are considered moderately resistant, while Asgrow/Monsanto AG 3003, BSR 101, Croton 3.9,
} Dairyland DSR272RR, Kaltenberg KB256RR, and Pioneer 9163 and 9363 are considered susceptible to Sclerotinia stem rot. 
arranged in a randomized complete block design with four replications, and the experiment was done twice.

Field experiments. In fields naturally infested with $S$. sclerotiorum, different methods were used to evaluate benomyl and/or thiophanate methyl between 1995 and 2000 in Illinois, Indiana, Ohio, and Wisconsin for efficacy against $S$. sclerotiorum on soybean. Field location, cultivar selection, seeding rate, row width, and previous crop are presented in Table 1.

Illinois and Indiana. In 1998, 1999, and 2000, field studies were conducted at Watseka and Woodstock, IL, and Kentland, IN, respectively, in infested fields to evaluate thiophanate methyl. The Watseka and Kentland locations had silt loam type soil, while the Woodstock location had sandy loam type soil. All three fields were tilled in the fall and spring prior to planting. Soybean cultivar Pioneer 9363 was planted in 6-row plots spaced $19 \mathrm{~cm}$ apart and 6.6 $\mathrm{m}$ long at 494,000 seeds per hectare. Thiophanate methyl was applied with a $\mathrm{CO}_{2}$ pressurized sprayer calibrated to deliver 238 liters/ha at $173 \mathrm{kPa}$ pressure using XR8003VS flat nozzles (Spraying Systems Co.). All applications were made at approximately $5.0 \mathrm{~km} / \mathrm{h}$ at the $\mathrm{R} 1$ or $\mathrm{R} 3$ growth stage over the entire plot. Treatments included thiophanate methyl applied at the R1 growth stage, thiophanate methyl applied at both the R1 and R3 growth stages, and a nontreated control. The treatments were arranged in a randomized block with five replications in 1998 and four replications in 1999 and 2000. Sclerotinia stem rot incidence was estimated by assessing 50 consecutive plants in each plot at the R7 growth stage (7). Plots were harvested with a Hege small plot combine (Waldenburg, Germany), and grain yields were adjusted to $13.5 \%$ moisture.

In a commercial field, water-sensitive paper cards for monitoring spray distribution (Syngenta, Basle, Switzerland) were placed on top of the canopy, $25 \mathrm{~cm}$ into the canopy, and on the soil surface inside the canopy. Pioneer 93B01 was planted with a row spacing of $19 \mathrm{~cm}$ at 494,000 seeds per hectare. Distilled water was applied at R2 previously described. Percent coverage was determined using a computer base area scanner (Root Analysis System Version growth stage using the same system as

0.95, Mark Belding, Illinois State Water Survey, 1998).

Ohio. Two different broadcast nozzles on a conventional sprayer and one nozzle on a Myers Mity Mist air assist sprayer (Ashland, $\mathrm{OH}$ ) were studied in infested fields using thiophanate methyl $(1.12 \mathrm{~kg}$ a.i./ha) in Ohio during the 1998, 1999, and 2000 growing seasons. All field locations were silt loam, and only the 1999 location was fall tilled prior to planting. The 1998 and 2000 fields were no-till. Fields were planted with a drill in 1998 and 2000 and a planter in 1999. The conventional broadcast sprayer had a boom length of $3.7 \mathrm{~m}$ with nozzles spaced $51 \mathrm{~cm}$ on center. Fungicide was applied at 187 liters/ha with two nozzles, XR8002 and D2-23 (Spray Systems Co., Wheaton, IL), at 296 and $1,654 \mathrm{kPa}$ pressure, respectively, at the R2 growth stage. The Myers Mity Mist sprayer used XR110015 nozzles at $193 \mathrm{kPa}$ pressure spaced $30 \mathrm{~cm}$ on center. The average air outlet speed was $20 \mathrm{~m} / \mathrm{s}$. The air and spray discharge was directed approximately $30^{\circ}$ back from vertical. All applications were made at $5.0 \mathrm{~km} / \mathrm{h}$. The six treatments consisted of a fungicide application with a conventional broadcast sprayer with XR8002 nozzles, conventional broadcast with D2-23 nozzles, and Myers air assist with XR110015 nozzles; the three controls were water applied with a conventional boom with XR8002 flat-fan nozzles or Myers air assist and nontreated. The treatments were applied to plots $3.7 \mathrm{~m}$ wide by $16.8 \mathrm{~m}$ long in a randomized block design with five replications in 1998 and 1999 and four replications in 2000. When the leaves were beginning to turn yellow (growth stage R7), the incidence of Sclerotinia stem rot from 200 consecutive plants in each plot was recorded. Plots, $3 \mathrm{~m}$ wide by $15 \mathrm{~m}$ long, were harvested with a Kincaid plot combine (Kincaid, KS), and yields were adjusted to $13.5 \%$ moisture.

Wisconsin. Evaluations of benomyl and thiophanate methyl were done in naturally infested fields located near Arlington and Waunakee, WI, from 1995 through 1999. A silt loam type soil was present at both locations, and fields were tilled in the fall and spring prior to planting. Seeds were planted in $3 \times 7.6 \mathrm{~m}$ plots at a density of 556,000 seeds per hectare in $19-\mathrm{cm}$ row spacing in all years of the study. Benomyl

Table 2. Area under mycelial growth curve (AUMGC) of Sclerotinia sclerotiorum grown on potato dextrose agar (PDA) amended with four fungicides at six concentrations ${ }^{\mathrm{a}}$

\begin{tabular}{lrrrccc}
\hline & \multicolumn{7}{c}{ Concentration ( $\boldsymbol{\mu g}$ a.i./ml of agar) } \\
\cline { 2 - 7 } Fungicide & $\mathbf{0 . 1}$ & $\mathbf{1}$ & $\mathbf{1 0}$ & $\mathbf{5 0}$ & $\mathbf{1 0 0}$ & $\mathbf{5 0 0}$ \\
\hline Benomyl & 240 & 73 & 5 & 4 & 2 & 0 \\
Tebuconazole & 211 & 24 & 0 & 0 & 0 & 0 \\
Thiophanate methyl & 236 & 82 & 52 & 7 & 6 & 4 \\
Vinclozolin & 67 & 8 & 0 & 0 & 0 & 0 \\
\hline
\end{tabular}

a AUMGC value for control (nonamended PDA) is 237. AUMGC calculated by: AUMGC $=\sum^{n-1}{ }_{i=1}$ $\left[\left(X_{i+1}+X_{i}\right) / 2\right]\left[t_{i+1}-t_{i}\right]$, in which $X_{i}=$ colony diameter, expressed in $\mathrm{mm}$ at the $i$ th observation, $t_{i}=$ time (days after inoculation) at the $i$ th observation, and $n=$ total number of observations. Least significant difference $(P \leq 0.05)=8.3$. was applied at 0.56 and $1.12 \mathrm{~kg}$ a.i./ha and thiophanate methyl was applied at 0.84 and $1.12 \mathrm{~kg}$ a.i./ha at either the $\mathrm{R} 1$ or $\mathrm{R} 2$ growth stage using a multiboom plot sprayer mounted on an IH Cub (Case International, Racine, WI). In 1995 and 1996, the system was calibrated to deliver 183 liters/ha at $228 \mathrm{kPa}$ pressure using SS730154 nozzles (Spraying Systems Co.). In 1997, 1998, and 1999, the system was calibrated to deliver 275 liters/ha at 241 $\mathrm{kPa}$ pressure using XR80015VS flat-fan nozzles (Spraying Systems Co.). All field experiments were designed as a randomized complete block with four to five replications. Sclerotinia stem rot incidence was recorded at growth stage $\mathrm{R} 7$ by a visual percent estimate of plants killed by $S$. sclerotiorum from the center of the plots. Plots were harvested with an Almaco plot combine (Allen Machine Co., Nevada, IA), and yields were adjusted to $13.5 \%$ moisture.

Data analysis. An analysis of variance of the AUMGC values was completed using the general linear models procedure (PROC GLM) in SAS (SAS Institute, Cary, NC) with trials treated as a random effect and fungicides and fungicide concentrations as fixed effects. Means were compared with Fisher's protected least significant difference test at $P \leq 0.05$. $\mathrm{EC}_{50}$ values for vinclozolin and thiophanate methyl were calculated from the regression line using the average diameter for each concentration. For the 91 isolates, an analysis of variance of the AUMGC values was completed using PROC GLM with replications treated as a random effect and isolates as a fixed effect for each treatment (nontreated control, thiophanate methylamended PDA, and vinclozolin-amended PDA). Means were compared with Fisher's protected least significant difference test at $P \leq 0.05$. For the greenhouse study, foliar ratings were analyzed with PROC GLM using replications and trial as random effects and plants, fungicide, and cultivar as fixed effects. For the detached leaf study, the AUDPC value was calculated and analyzed with PROC GLM using replications and trial as random effects and fungicide and cultivar as fixed effects. The interaction between fungicide and cultivar was also analyzed. For the field studies, each location-year combination was analyzed separately. An analysis of variance of the percent Sclerotinia stem rot and yield was completed using PROC GLM in SAS with replications designated as a random effect and application method with or without fungicide as a fixed effect. Means were separated with the Fisher's protected least significant difference test at $P \leq 0.05$, except for the means from the Wisconsin study, which were at $P \leq 0.10$.

\section{RESULTS AND DISCUSSION}

In vitro growth of $S$. sclerotiorum on fungicide-amended agar. Agar amended with each of the four fungicides reduced 
mycelial growth of S. sclerotiorum compared with the growth on nonamended PDA (Table 2). Vinclozolin inhibited mycelial growth at $1 \mu \mathrm{g}$ a.i./ml of agar; benomyl and tebuconazole at $10 \mu \mathrm{g}$ a.i. $/ \mathrm{ml}$ of agar; thiophanate methyl at $50 \mu \mathrm{g}$ a.i./ml of agar. Our findings are similar to a previous report where vinclozolin completely inhibited mycelial growth at $1 \mu \mathrm{g}$ a.i./ml of agar (23). In addition, benomyl and thiophanate methyl were reported to reduce mycelial growth 80 to $90 \%$ at $5 \mu \mathrm{g}$ a.i./ml of agar (11). The $\mathrm{EC}_{50}$ values in our study for vinclozolin and thiophanate methyl were 0.6 and $2.2 \mu \mathrm{g}$ a.i./ml of PDA, respectively.

In vitro studies have been used to identify specific fungicides and rates for fungicidal activity against $S$. sclerotiorum (11). In addition, many isolates of $S$. sclerotiorum must be evaluated to detect the presence of strains that express resistance to fungicides. Screening fungicides at different concentrations against many isolates can potentially identify fungicides that may have limited efficacy against $S$. sclerotiorum. In our study, there were differences $(P<0.01)$ in rate of mycelial growth among the 91 isolates in the nonamended PDA, thiophanate methyl- and vinclozolinamended PDA. All the isolates completely colonized the agar in the petri dishes within 3 days on the nonamended PDA. The AUMGC value for the nonamended PDA ranged from 127 to 224 . Mean mycelial growth of all isolates in the thiophanate methyl- and vinclozolin-amended agar was reduced 18 to $93 \%$ and 93 to $99 \%$, respectively, when compared with the nonamended control (Table 3 ).

In a previous study, no resistance to benomyl was detected within $100 \mathrm{~S}$. sclerotiorum isolates collected from a snap bean field treated with benomyl (14). However, field isolates with resistance to fungicides have been reported in other Sclerotinia spp. affecting peanut (Arachis hypogaea L.) in Virginia (5), lettuce (Lactuca sativa L.) in California (13), and creeping bentgrass (Agrostis palustris Huds.) in Michigan (6). Hubbard et al. (13) attributed the failure to control $S$. minor with fungicides in the field to fungicideresistant isolates. The variation in sensitivity to thiophanate methyl observed in 91 isolates indicates that the potential for fungicide resistance in $S$. sclerotiorum exists. However, there was very little variation in sensitivity to vinclozolin. With the variation in $S$. sclerotiorum to thiophanate methyl, there is a need to identify fungicides with different modes of action to control Sclerotinia stem rot. These fungicides with different modes of action could be used in a rotation to help manage further development of fungicide-resistant isolates of $S$. sclerotiorum.

Greenhouse experiments. There was a significant $(P<0.01)$ effect among the four fungicides tested on disease severity, but not a significant effect of cultivar, plant, or any interactions $(P \leq 0.05)$. Plants treated with benomyl, thiophanate methyl, and vinclozolin did not express symptoms or signs of Sclerotinia stem rot (Table 4). Plants treated with tebuconazole had both restricted and expanded lesions on leaves, but no stem symptoms or signs were observed. All the plants treated with fungicides survived the inoculation and added new leaves. Plants not sprayed with a fungicide had expanded foliar lesions that caused defoliation, fungal colonized stems, and some dead plants (Table 4). These results agree with previous studies showing that spraying the entire plant with effective fungicides will provide excellent control of S. sclerotiorum (14).

Ascospore colonization of blossoms causes the primary infection (1), while secondary infection may also occur on leaves, petioles, and stems from direct contact with infected blossoms and diseased adjacent plants. The inoculation procedure used in this study is similar to natural infection resulting from direct contact. Therefore, with the control exhibited in the greenhouse using this inoculation technique, there is a potential to control secondary spread of Sclerotinia stem rot.

Table 3. Host, location, area under mycelial growth curve (AUMGC), and percent reduction of mycelial growth from thiophanate methyl and vinclozolin for isolates ${ }^{\mathrm{a}}$ of Sclerotinia sclerotiorum

\begin{tabular}{|c|c|c|c|c|c|}
\hline Isolate $^{a}$ & Host & $\begin{array}{l}\text { County, state, } \\
\text { or country }\end{array}$ & $\begin{array}{l}\text { Nonamended } \\
\text { AUMGC }^{\mathbf{b}}\end{array}$ & $\begin{array}{c}\text { Vinclozolin }^{\mathrm{c}} \\
(\% \text { inhibition })^{\mathrm{d}}\end{array}$ & 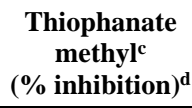 \\
\hline 3 & Unknown & North Carolina & 203 & 97.2 & 17.7 \\
\hline 151 & Soybean & LaSalle Co., IL & 204 & 94.1 & 27.3 \\
\hline 28 & Soybean & Iroquois Co., IL & 215 & 96.5 & 27.6 \\
\hline 103 & Soybean & Macon Co., IL & 220 & 94.8 & 29.8 \\
\hline 160 & Soybean & Argentina & 210 & 97.1 & 37.7 \\
\hline 34 & Rape & Canada & 210 & 94.3 & 40.7 \\
\hline 110 & Pear & Oregon & 188 & 95.8 & 46.0 \\
\hline 113 & Soybean & Henry Co., IL & 221 & 98.6 & 66.2 \\
\hline 105 & Soybean & Iowa & 214 & 98.4 & 68.4 \\
\hline 7 & Dry bean & Scotts Bluff, NE & 206 & 95.4 & 69.0 \\
\hline 144 & Sunflower & Switzerland & 206 & 94.7 & 69.3 \\
\hline 16 & Soybean & Rock Co., WI & 212 & 96.8 & 78.8 \\
\hline 152 & Soybean & Champaign Co., IL & 209 & 96.9 & 84.5 \\
\hline 87 & Soybean & Indiana & 202 & 97.8 & 88.6 \\
\hline 149 & Soybean & Ingham Co., MI & 189 & 98.3 & 93.2 \\
\hline \multicolumn{3}{|l|}{ Mean } & 208 & 96.8 & 59.5 \\
\hline \multicolumn{3}{|c|}{ Range } & 127 to 224 & 93 to 99 & 18 to 93 \\
\hline \multicolumn{3}{|c|}{$\operatorname{LSD}(P<0.01)^{\mathrm{e}}$} & 10.2 & 2.0 & 16.1 \\
\hline
\end{tabular}

a A total of 91 isolates of Sclerotinia sclerotiorum from the soybean pathogen collection housed at the National Soybean Research Center at the University of Illinois were screened for sensitivity to thiophanate methyl and vinclozolin. The 15 isolates presented here represent different host, locations, and reaction to thiophanate methyl.

${ }^{\mathrm{b}}$ AUMGC calculated by: AUMGC $=\sum_{i=1}^{n-1}\left[\left(X_{i+1}+X_{i}\right) / 2\right]\left[t_{i+1}-t_{i}\right]$, in which $X_{i}=$ colony diameter, expressed in $\mathrm{mm}$ at the $i$ th observation, $t_{i}=$ time (days after inoculation) at the $i$ th observation, and $n=$ total number of observations.

${ }^{c}$ Vinclozolin and thiophanate methyl both were used at $1 \mu \mathrm{g}$ a.i./ml in potato dextrose agar (PDA).

${ }^{d}$ Percent inhibition of mycelial growth for each fungicide was calculated by dividing the AUMGC of the fungicide amended PDA by the AUMGC of the nonamended PDA for each replication.

e LSD = Fisher's protected least significant difference.

Table 4. Disease severity ratings for fungicide treated and untreated soybean seedlings and detached leaves that were inoculated with Sclerotinia sclerotiorum in the greenhouse

\begin{tabular}{lccc}
\hline Fungicide & $\begin{array}{c}\text { Rates } \\
\text { (kg a.i./ha) }\end{array}$ & $\begin{array}{c}\text { Disease severity } \\
\text { (seedlings) }\end{array}$ & $\begin{array}{c}\text { AUDPC }^{\mathbf{b}} \\
\text { (detached leaves) }\end{array}$ \\
\hline Nontreated control & - & 2.7 & 48.7 \\
Benomyl & 0.56 & 0.0 & 1.7 \\
Tebuconazole & 0.13 & 1.1 & 0.8 \\
Thiophanate methyl & 0.78 & 0.0 & 0.0 \\
Vinclozolin & 1.12 & 0.0 & 0.0 \\
LSD $(P<0.01)^{\mathrm{c}}$ & & $0.3^{\mathrm{d}}$ & $4.7^{\mathrm{e}}$ \\
\hline
\end{tabular}

a Seedlings inoculated in greenhouse and rated on a scale of 0 to 5 , where $0=$ no disease, $1=$ restricted lesion on leaf, 2 = lesion expanded on leaf, 3 = leaf with expanded lesion and start of stem colonization, 4 = severe stem colonization, 5 = plant completely dead.

${ }^{\mathrm{b}}$ Detached leaflets sprayed with fungicides and inoculated with an inverted PDA plug with $S$. sclerotiorum. AUDPC calculated by: AUDPC $=\sum^{n-1}{ }_{i=1}\left[\left(X_{i+1}+X_{i}\right) / 2\right]\left[t_{i+1}-t_{i}\right]$ in which $X_{i}=$ lesion diameter, expressed in $\mathrm{mm}$ at the $i$ th observation, $t_{i}=$ time (days after inoculation) at the $i$ th observation, and $n=$ total number of observations.

${ }^{c}$ LSD $=$ Fisher's protected least significant difference.

d Benomyl, thiophanate methyl, and vinclozolin not included in analysis of variance.

e Thiophanate methyl and vinclozolin not included in analysis of variance. 
The detached leaf assay used in our experiments to evaluate fungicide efficacy is similar to a method previously used to screen alfalfa (Medicago sativa L.) and soybean for resistance to $S$. sclerotiorum $(16,22)$. Thiophanate methyl and vinclozolin prevented S. sclerotiorum from colonizing the detached leaf beyond the initial PDA plug. AUDPC was greater $(P<0.01)$ for the no fungicide control (Table 4) compared with the fungicide treatments. There was no significant difference between NK S19-90 and BSR 101 with any fungicide or the inoculated control.

Field experiments. Of the 12 different environments in Illinois, Ohio, and Wisconsin, 11 included at least one cultivar

Table 5. Sclerotinia stem rot incidence and soybean seed yield for Pioneer 9363 treated with thiophanate methyl at Watseka, IL, in 1998

\begin{tabular}{lccc}
\hline Treatment & $\begin{array}{c}\text { Rate } \\
(\mathbf{k g} \text { a.i./ha) }\end{array}$ & $\begin{array}{c}\text { Disease incidence } \\
(\mathbf{\%})^{\mathbf{a}}\end{array}$ & $\begin{array}{c}\text { Yield } \\
(\mathbf{k g} / \mathbf{h a})\end{array}$ \\
\hline Dry control & - & 57.0 & 3,287 \\
Thiophanate methyl & $1.12(\mathrm{R} 1)^{\mathrm{b}}$ & 61.0 & 3,001 \\
Thiophanate methyl & $1.12(\mathrm{R} 1)+1.12(\mathrm{R} 3)$ & 63.0 & 3,154 \\
LSD $(P \leq 0.05)$ & & n.s. & n.s. \\
\hline
\end{tabular}

${ }^{a}$ Disease incidence was determined by the number of diseased plants out of 50 in each plot.

b Thiophanate methyl applied at growth stages R1 and R3 using a $\mathrm{CO}_{2}$ pressurized sprayer calibrated to deliver 238 liters/ha at $173 \mathrm{kPa}$ pressure using XR8003VS flat spray tips.

Table 6. Sclerotinia stem rot incidence and yield from a comparison of two spray application techniques with thiophanate methyl for control of Sclerotinia sclerotiorum of soybean in Ohio in 1998 and 2000

\begin{tabular}{|c|c|c|c|c|c|c|}
\hline \multirow[b]{3}{*}{ Treatment } & \multirow[b]{3}{*}{ Sprayer } & \multirow[b]{3}{*}{ Nozzle } & \multicolumn{4}{|c|}{ Year } \\
\hline & & & \multicolumn{2}{|c|}{1998} & \multicolumn{2}{|c|}{2000} \\
\hline & & & $\begin{array}{c}\text { SSR }^{\mathbf{a}} \\
(\%)\end{array}$ & $\begin{array}{c}\text { Yield } \\
(\mathrm{kg} / \mathrm{ha})\end{array}$ & $\begin{array}{l}\text { SSR } \\
(\%)\end{array}$ & $\begin{array}{c}\text { Yield } \\
\text { (kg/ha) }\end{array}$ \\
\hline Nontreated $^{b}$ & - & - & 22.0 & 2,949 & 57.1 & 2,848 \\
\hline \multirow[t]{2}{*}{ Wet control $^{\mathrm{b}}$} & $\begin{array}{c}\text { Conventional } \\
\text { broadcast }\end{array}$ & XR8002 & 13.5 & 3,367 & 66.6 & 2,815 \\
\hline & Myers Mity Mist & XR110015 & 22.0 & 3,219 & - & - \\
\hline \multirow[t]{3}{*}{$\begin{array}{l}\text { Thiophanate } \\
\text { methyl }^{\mathrm{c}}\end{array}$} & $\begin{array}{l}\text { Conventional } \\
\text { broadcast }\end{array}$ & XR8002 & 9.5 & 3,852 & 62.7 & 2,902 \\
\hline & $\begin{array}{c}\text { Conventional } \\
\text { broadcast }\end{array}$ & D2-23 & 10.5 & 3,818 & 53.5 & 3,037 \\
\hline & Myers Mity Mist & XR110015 & 11.0 & 4,263 & 42.3 & 3,731 \\
\hline \multicolumn{2}{|c|}{$\operatorname{LSD}(P \leq 0.05)$} & & 8.9 & 646 & n.s. & n.s. \\
\hline
\end{tabular}

a SSR is Sclerotinia stem rot; SSR incidence determined by the number of plants with Sclerotinia stem rot out of 200 in each plot.

${ }^{\mathrm{b}}$ Nothing was applied on the soybean plants for the nontreated; wet control water was applied.

${ }^{\mathrm{c}}$ Thiophanate methyl was applied at $1.12 \mathrm{~kg}$ a.i./ha at the $\mathrm{R} 2$ growth stage.

Table 7. Comparison of fungicides and rate of application at the R1 growth stage for the control of Sclerotinia stem rot of soybean in Wisconsin in 1995 and 1996

\begin{tabular}{|c|c|c|c|c|c|}
\hline \multirow[b]{2}{*}{ Treatment } & \multirow[b]{2}{*}{$\begin{array}{c}\text { Rate } \\
\text { (kg a.i./ha) }\end{array}$} & \multicolumn{2}{|c|}{1995} & \multicolumn{2}{|c|}{1996} \\
\hline & & $\begin{array}{c}\operatorname{SSR}^{\mathbf{a}, \mathrm{b}} \\
(\%)\end{array}$ & $\begin{array}{c}\text { Yield }{ }^{\text {b }} \\
\text { (kg/ha) }\end{array}$ & $\begin{array}{c}\operatorname{SSR}^{\mathbf{a}, \mathrm{b}} \\
(\%)\end{array}$ & $\begin{array}{c}\text { Yield }^{\mathrm{b}} \\
\text { (kg/ha) }\end{array}$ \\
\hline Dry control & - & 23 & 3,881 & 47 & 2,606 \\
\hline \multirow{2}{*}{ Benomyl } & 0.56 & 21 & 3,749 & 52 & 2,703 \\
\hline & 1.12 & 20 & 4,026 & 35 & 2,758 \\
\hline \multirow{2}{*}{ Thiophanate methyl } & 0.84 & 21 & 3,701 & 49 & 2,703 \\
\hline & 1.12 & 20 & 4,123 & 38 & 2,779 \\
\hline $\operatorname{LSD}(P \leq 0.10)$ & & n.s. & 201 & 7 & n.s. \\
\hline
\end{tabular}

a SSR is Sclerotinia stem rot; SSR incidence was recorded at growth stage R7 by a visual percent estimate of plants killed by Sclerotinia sclerotiorum from the center of the plots.

${ }^{\mathrm{b}}$ Averaged from three cultivars NK Brand S19-90, BSR101, and Sturdy. both nozzles and the air assist sprayer, significantly $(P \leq 0.05)$ reduced the incidence of Sclerotinia stem rot compared with air assist water and nontreated controls in 1998 (Table 6). Interestingly, water applied with the conventional sprayer also reduced Sclerotinia stem rot. Applications of water to soybean plants have reduced the incidence of Sclerotinia stem rot in other trials (A. Dorrance, B. Diers, J. Kurle, C. Grau, B. Potter, and X. B. Yang, unpublished data). However, the question of water having a direct effect on the infection process or diluting ascospore inoculum present at the time of application is an area that warrants further research. All of the application techniques with thiophanate methyl significantly increased yields $(P \leq$ 0.05) in 1998 compared with the nontreated control. Using the same two spray systems in 1999 and 2000, there was no disease, or no control of Sclerotinia stem rot, respectively. There was also no effect of fungicide on yield in 1999 and 2000. For the Wisconsin study in 1995, there were moderate levels of disease (range 20 to $23 \%$ incidence). The fungicide applications had no effect on disease incidence; however, there was a significant $(P$ $=0.10$ ) increase in yield for thiophanate methyl at $1.12 \mathrm{~kg}$ a.i./ha compared with the control and the low rates of thiophanate methyl and benomyl (Table 7). This yield increase was apparently not related to control of Sclerotinia stem rot. In 1996, disease incidence was higher than in 1995 (range 35 to $52 \%$ incidence); however, there was no significant effect on yield for any treatments (Table 7). In 1997, although there were varying levels of Sclerotinia stem rot, there were no statistical differences in disease incidence or yield between the treated and untreated plots. In 1998 and 1999 , there was very low disease incidence.

Previous reports have demonstrated inconsistent control of $S$. sclerotiorum in the field with fungicides in different bean species: dry bean ( $P$. vulgaris) (26), lima bean (Phaseolus lunatus L.) (21), snap bean $(2,8,14,15,18,21)$ and white bean $(P . v u l$ garis) (19). From our greenhouse and detached leaf assays, fungicides were able to control Sclerotinia stem rot on soybean in the greenhouse. However, we were not able to obtain consistent, adequate levels of control of Sclerotinia stem rot in the field in a number of field locations and environments. Several reasons could contribute to the lack of control. First, there could be isolates of S. sclerotiorum with resistance to thiophanate methyl and benomyl present in these field environments. Although we found isolates with varying levels of resistance to thiophanate methyl, this only demonstrates that there is potential for the fungus to be insensitive. The greenhouse study with four fungicides showed excellent control with complete coverage. Thus, another possible explanation would be 
poor coverage of the fungicide on the existing infection sites as well as additional blossoms developing after fungicide has been applied. High yield management practices such as early planting, narrow row spacings, and high seeding rates were utilized in all experiments. While these practices contributed to an environment conducive for Sclerotinia stem rot development, the ability of fungicides to penetrate the soybean canopy was limited. The inability of fungicides to penetrate the soybean canopy resulted in poor coverage of soybean blossoms. The water-sensitive paper indicated that there was $<1 \%$ coverage at the soil surface under the soybean canopy, and $<2 \%$ coverage $25 \mathrm{~cm}$ below the top of the canopy, compared with about $80 \%$ coverage on the top of the canopy using the $\mathrm{CO}_{2}$ pressurized sprayer system in the Illinois field study. The importance of covering blossoms with fungicides was reported on snap bean $(14,19)$. With complete coverage, fungicides may control Sclerotinia stem rot $(4,14,19)$, but a more efficient method of penetrating the canopy with fungicide in the field, especially in the 19-cm rows, needs to be identified. In 76$\mathrm{cm}$ rows, using three flat-fan nozzles (1 nozzle horizontal above the row and 1 on each side of row spraying downward) for applying benomyl suppressed disease development and increased seed yield of white bean, compared with using only one flat-fan nozzle per row (19). Additional advantages of penetrating the soybean canopy would be covering the soil surface with the fungicide. This may result in reducing sclerotial germination, apothecial production by germinating sclerotia, rate of apothecial production, and delay in apothecial emergence (28).

Further studies are needed on application techniques such as drop nozzles or with fungicides that will systemically move down the plant to protect the stems. In these field evaluations, the studies were established in fields with a history of Sclerotinia stem rot and managed to provide an environment conducive to Sclerotinia stem rot development. However, over the different years and environments, disease developed $40 \%$ of the time. Even if soybean blossoms were protected with fungicide, there would be no advantage to applying fungicides in years with no disease. Although further research and technology are needed to achieve greater efficacy of fungicides, research to more accurately fore- cast Sclerotinia stem rot epidemics is equally important in order to manage Sclerotinia stem rot in a profitable manner.

\section{ACKNOWLEDGMENTS}

Salaries and research support provided in part by the North Central Soybean Research Program (NCSRP), Illinois Soybean Program Operating Board (ISPOB), Ohio Soybean Council, Wisconsin Soybean Marketing Board, the state and federal funds appropriated to the Ohio Agricultural Research and Development Center and College of Agriculture and Life Sciences, University of Wisconsin-Madison. We thank K. A. Ames, L. S. Kull, J. B. Manandhar, and J. W. Mueller for their assistance in completing the laboratory and field work in Illinois; and S. A. McClure, J. Siefker, A. Doklovic, B. Anderson, O. Bostan, and L. Cai for their assistance in completing field studies in Ohio.

\section{LITERATURE CITED}

1. Abawi, G. S., Polach, F. J., and Molin, W. T. 1975. Infection of bean by ascospores of Whetzelinia sclerotiorum. Phytopathology 65:673-678.

2. Beckman, K. M., and Parsons, J. E. 1965. Fungicidal control of Sclerotinia wilt in green beans. Plant Dis. Rep. 49:357-358.

3. Boland, G. J., and Hall, R. 1988. Epidemiology of Sclerotinia stem rot of soybean in Ontario. Phytopathology 78:1241-1245.

4. Bowerman, P., and Gladders, P. 1993. Evaluation of fungicides against Sclerotinia sclerotiorum. Ann. Appl. Biol. Sup. 122:42-43.

5. Brenneman, T. B., Phipps, P. M., and Stipes, R. J. 1987. In vivo dicarboximide resistance in Sclerotinia minor from peanut. (Abstr.) Phytopathology 77:639.

6. Detweiler, A. R., Vargas, J. M., Jr., and Danneberger, T. K. 1983. Resistance of Sclerotinia homeocarpa to iprodione and benomyl. Plant Dis. 67:627-630.

7. Fehr, W. R., Caviness, C. E., Burmood, D. T., and Pennington, J. S. 1971. Stage development descriptions for soybeans, Glycine max (L.) Merrill. Crop Sci. 11:929-931.

8. Gabrielson, R. L., Guilford, R. K., and Coahran, D. R. 1971. Field control of white mold and gray molds of beans in western Washington. Plant Dis. Rep. 55:234-238.

9. Grau, C. R., Adee, E. A., and Oplinger, E. S. 1994. An integrated approach to control Sclerotinia stem rot (White Mold) in soybean. Pages 183-196 in: Proc. Integrated Crop Management Conf. 1994.

10. Hartman, G. L., Kull, L., and Huang, Y. H. 1998. Occurrence of Sclerotinia sclerotiorum in soybean fields in east-central Illinois and enumeration of inocula in soybean seed lots. Plant Dis. 82:560-564.

11. Hawthorne, B. T., and Jarvis, W. R. 1973. Differential activity of fungicides on various stages in the life cycle of Sclerotinia spp. N.Z. J. Agric. Res. 16:551-557.

12. Hoffman, D. D., Hartman, G. L., Mueller, D. S., Leitz, R. A., Nickell, C. D., and Pedersen, W. L. 1998. Yield and seed quality of soybean cultivars infected with Sclerotinia sclerotiorum. Plant Dis. 82:826-829.
13. Hubbard, J. C., Subbarao, K. V., and Koike, S. T. 1997. Development and significance of dicarboximide resistance in Sclerotinia minor isolates from commercial lettuce fields in California. Plant Dis. 81:148-153.

14. Hunter, J. E., Abawi, G. S., and Crosier, D. C. 1978. Effects of timing, coverage, and spray oil on control of white mold of snap bean with benomyl. Plant Dis. Rep. 62:633-637.

15. Kerr, E. D., Smith, A. C., Yonts, C. D., and Wilson, R. G. 1992. Fungicide efficacy for bean white mold under different plant populations and row spacings. Annu. Rep. Bean Improve. Corp. 35:52-53.

16. Kim, H. S., Hartman, G. L., Manandhar, J. B., Graef, G. L., Steadman, J. R., and Diers, B. W. 2000. Reaction of soybean cultivars to Sclerotinia stem rot in field, greenhouse, and laboratory evaluations. Crop Sci 40:665-669.

17. Manandhar, J. B., Kull, L. S., Pedersen, W. L., and Hartman, G. L. 1998. Aggressiveness of Sclerotinia sclerotiorum isolates and evaluation of soybeans for resistance to Sclerotinia stem rot. (Abstr.) Phytopathology 88:S57.

18. McMillan, R. T., Jr. 1973. Bean white mold control. Fla. State Hortic. Soc. 86:165-166.

19. Morton, J. G., and Hall, R. 1989. Factors determining the efficacy of chemical control of white mold in white bean. Can. J. Plant Pathol. 11:297-302.

20. Mueller, D. S., Hartman, G. L., and Pedersen, W. L. 1999. Development of sclerotia and apothecia of Sclerotinia sclerotiorum from infected soybean seed and its control by fungicide seed treatment. Plant Dis. 83:1113-1115.

21. Niedbalski, J. F., and Rickard, S. F. 1969. Sclerotinia white mold control in snap and lima beans with 2,6-dichlor-4-nitroanline. Plant Dis. Rep. 53:573-575.

22. Pratt, R. G. 1996. Screening for resistance to Sclerotinia trifoliorum in alfalfa by inoculation of excised leaf tissue. Phytopathology 86:923-928.

23. Reichard, S. L., Sulc, R. M., and Rhodes, L. H. 1997. Growth and reproduction of Sclerotinia trifoliorum as influenced by herbicides. Mycologia 89:82-88.

24. Steadman, J. R. 1979. Control of plant diseases caused by Sclerotinia species. Phytopathology 69:904-907.

25. Tooley, P. W., and Grau, C. R. 1984. Field characterization of rate-reducing resistance to Phytophthora megasperma f. sp. glycinea in soybean. Phytopathology 74:1201-1208.

26. Varner, G. 1986. White mold control programs on irrigated dry beans. Annu. Rep. Bean Improvement Corp. 29:56-57.

27. Wrather, J. A., Anderson, T. R., Arsyad, D. M., Gai, J., Ploper, L. D., Porta-Puglia, A., Ram, H. H., and Yorinori, J. T. 1997. Soybean disease loss estimates for the top 10 soybean producing countries in 1994. Plant Dis. 81:107-110.

28. Yarden, O., Ben-Yephet, Y., Katan, J., and Aharonson, N. 1986. Fungicidal control of Sclerotinia sclerotiorum in soil with a combination of benomyl and thiram. Plant Dis. 70:738-742. 